\title{
Differential role of diphenyleneiodonium, a flavoenzyme inhibitor, on p53-dependent and -independent cell cycle progression
}

\author{
JU DONG SONG ${ }^{1,4}$, KANG MI KIM ${ }^{1}$, KOAN HOI KIM ${ }^{2}$, CHI DAE KIM ${ }^{2,3}$, \\ JONG MIN KIM ${ }^{4}$, YOUNG HYUN YOO ${ }^{4}$ and YOUNG CHUL PARK ${ }^{1}$ \\ ${ }^{1}$ Department of Microbiology and Immunology, Pusan National University School of Medicine; \\ ${ }^{2}$ Department of Pharmacology, Pusan National University School of Medicine; ${ }^{3} \mathrm{MRC}$ for Ischemic \\ Tissue Regeneration, Pusan National University, Busan 602-739; ${ }^{4}$ Dong-A University \\ Medical Science Research Center, Dong-A University, Busan 602-714, Korea
}

Received July 2, 2008; Accepted September 23, 2008

DOI: 10.3892/ijo_00000121

\begin{abstract}
We investigated the differential role of diphenyleneiodonium (DPI), which is widely used as an inhibitor of NADPH oxidase, on the activation of cell cycle regulators in the cell cycle progression. DPI efficiently blocked the transition from $\mathrm{G}_{0} / \mathrm{G}_{1}$ to $\mathrm{S}$ phase by serum stimulation in quiescent HCT-116 (wild-type p53) and HL-60 (null p53) cells. Concomitant with $\mathrm{G}_{0} / \mathrm{G}_{1}$ arrest, HCT-116 cells treated with DPI resulted in strong and sustained upregulation of p53 and p21. p53- or p21-deficient HCT-116 cells using a small interfering RNA (siRNA) significantly increased the progression into $\mathrm{S}$ phase by stimulation of DPI, compared with DPI alone. However, the silencing of p53 resulted in more efficient transition into $\mathrm{S}$ phase than the silencing of p21 siRNA and significantly inhibited p21 upregulation by DPI stimulation. Interestingly, brief exposure to DPI did not change p53 expression, but showed transient upregulation of p2 1 and $G_{0} / G_{1}$ arrest. These results suggest that p53 upregulation sustains $G_{0} / G_{1}$ cell cycle arrest and $\mathrm{p} 21$ upregulation by DPI stimulation in HCT-116 cells. In HL-60 cells, DPI also induced p21 upregulation in a p53-independent manner and the increase of p21 expression seems to be
\end{abstract}

Correspondence to: Dr Young Chul Park, Department of Microbiology and Immunology, Pusan National University School of Medicine, Busan 602-739, Korea

E-mail: ycpark@pusan.ac.kr

Abbreviations: DPI, diphenyleneiodonium; ROS, reactive oxygen species; PI, propidium iodide; DMSO, dimethyl sulfoxide; HRP, horseradish peroxide; ECL, enhanced chemiluminescence; FBS, fetal bovine serum; siRNA, small interfering RNA

Key words: diphenyleneiodonium, cell cycle, p53, cyclin D1, ERK activation regulated by DPI-mediated ERK activation. Cyclin D1 expression was not significantly affected by DPI treatment in HCT-116 cells. However, in HL-60 cells, DPI irreversibly impaired cyclin D1 upregulation by serum stimulation and a much greater fraction of cells arrested in $G_{0} / G_{1}$ was observed in HL-60 cells than in HCT-116 cells at $24 \mathrm{~h}$ after brief DPI treatment. These results suggest that cyclin D1 is an important regulatory factor in the inhibition of cell cycle progression by DPI in HL-60 cells.

\section{Introduction}

Diphenyleneiodonium (DPI) irreversibly inactivates flavoprotein-containing systems including NADPH oxidase $(1,2)$, nitric oxide synthase $(3)$, cytochrome P450 reductase (4) and other oxidoreductases (5-7). Electron transport through the flavin moieties of these flavoenzymes causes reduction of DPI to its diphenyleneiodonyl radical form, followed by covalent phenylation of either the flavin or the adjacent amino acid and heme groups of the proteins $(8,9)$. Despite its nonspecific mode of action, DPI has been used extensively to block reactive oxygen species (ROS) generation mediated by NADPH oxidase in various cell types $(2,10,11)$, where the resultant oxidants are proposed to play a role in cell signaling in mitogenesis and cell proliferation $(12,13)$.

Some studies have shown that ROS have dose-dependent effects on cell cycle progression by modulating cyclin D1 expression (14,15). Recently, Nox1, NADPH oxidase homologue, has been reported to promote proliferation in murine epithelial C10 cells by sustaining expression of cyclin D1 under serum-starved conditions. Moreover, DPI markedly inhibited the induction of cyclin D1 needed for cell cycle re-entry through inhibition of Nox activity (16). However, DPI was also reported to affect cell cycle-mediated proliferation in a ROS-independent manner and this antiproliferative effect of DPI correlates with its ability to impair cyclin B1 (17).

More recently, DPI was also found to induce the expression of p53 in a ROS-independent manner (18). p53 can direct the cellular machinery towards cell cycle delay and apoptosis 
$(19,20)$. The main effector of p53-mediated cell cycle arrest is the p53 target gene, p21, which is known to be an inhibitor of cyclin-dependent kinases (21-23). However, DPI has also been reported to decrease p21 expression with activation of p53 in quiescent human fibroblast cells (24). Likewise, mechanistic information available on DPI-induced inhibition of cell cycle progression is still controversial and limited, although some studies on the anti-proliferative effect by DPI have been reported.

The present study was undertaken to define the role of cell cycle regulators such as p53, p21 and cyclin D1 in the inhibition of cell cycle progression by DPI. In this study, we used two cancer cell lines that exhibit differential regulation in the induction of cell cycle regulators by DPI. We show that the inhibition of transition from $\mathrm{G}_{0} / \mathrm{G}_{1}$ to $S$ phase by DPI is regulated in a p53-dependent or -independent manner depending on cell type. We further demonstrate that DPIinduced p53 expression is associated with the maintenance of $\mathrm{G}_{0} / \mathrm{G}_{1}$ arrest and $\mathrm{p} 21$ upregulation rather than with their initiation.

\section{Materials and methods}

Reagents. DPI, propidium iodide (PI), protease inhibitor cocktail, trypan blue $(0.4 \%)$, U0126 and dimethyl sulfoxide (DMSO) were purchased from Sigma-Aldrich Chemical Co. (St. Louis, MO). Anti-p53, p21, ERK, p-ERK and B-actin antibodies were purchased from Santa Cruz Biotechnology (Santa Cruz, CA). Anti-cyclin D1 antibody was obtained from Cell Signaling Technology (Beverly, MA). The secondary horseradish peroxide (HRP)-conjugated antibody and the enhanced chemiluminescence (ECL) Western blotting kits were obtained from Amersham Pharmacia Biotech (Piscataway, NJ). Fetal bovine serum (FBS), HBSS and other tissue culture reagents were purchased from Life Technologies (Gaithersburg, MD).

Cell culture and serum deprivation. Human colorectal cancer cell line HCT-116 and promyelocytic leukemia cell line HL-60 were grown in DMEM and RPMI-1640 medium, respectively, supplemented with $10 \% \mathrm{FBS}$ and antibiotics $(100 \mathrm{U} / \mathrm{ml}$ penicillin, $100 \mu \mathrm{g} / \mathrm{ml}$ streptomycin) at $37^{\circ} \mathrm{C}$ in a $5 \% \mathrm{CO}_{2}$ atmosphere. To maintain reproducibility, confluent HCT-116 cells were subcultured according to standard protocol with $0.01 \%$ trypsin-EDTA. To synchronize cells at the $\mathrm{G}_{0} / \mathrm{G}_{1}$ phase by serum deprivation (25), HCT-116 and HL-60 cells were incubated in the appropriate medium, with $0.5 \%$ FBS for $48 \mathrm{~h}$, before $10 \%$ FBS was added to induce the cells to re-enter the cell cycle. DPI was dissolved in DMSO prior to addition to the cultures. As a control, an equal amount of DMSO $(<0.03 \%)$ was added to untreated cells.

Evaluation of cell viability. For cell viability and proliferation analyses, HCT-116 and HL-60 cells were plated at $1 \times 10^{5}$ cells per $60-\mathrm{mm}$ dish. HCT-116 cells were further incubated for $12 \mathrm{~h}$. The cells were then cultured in the presence or absence of different concentrations of DPI in fresh medium supplemented with $10 \%$ FBS and collected at $24 \mathrm{~h}$ after DPI treatment. Cells were resuspended in the appropriate medium and viable and dead cells were counted by the trypan
A)

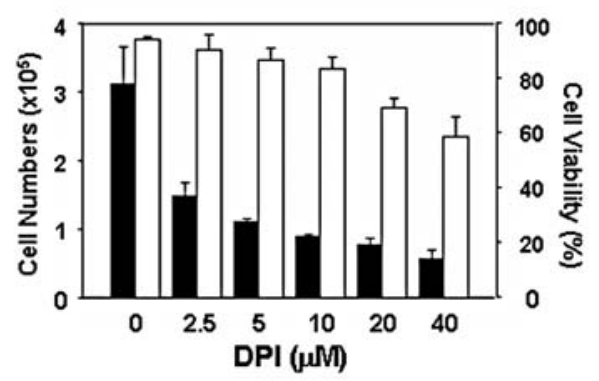

B)

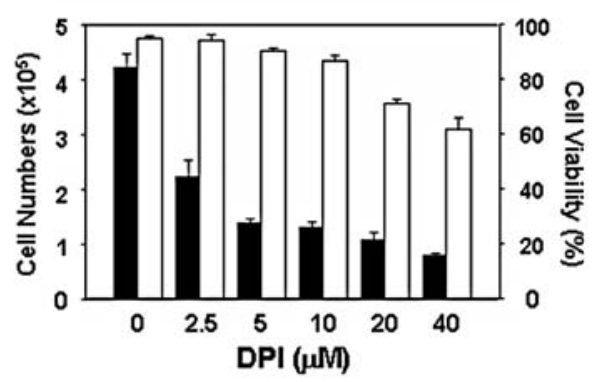

Figure 1. Effects of DPI on cell viability and proliferation. Cell viability ( $\square$, viable cells/total cells) and cell numbers ( $\square$, viable cells) were assessed by trypan blue dye exclusion assay at $24 \mathrm{~h}$ after DPI treatment at the indicated concentrations in HCT-116 (A) and HL-60 cells (B). The results are means $\pm \mathrm{SE}$ of three independent experiments.

blue dye exclusion method using a hemocytometer, as previously described (26).

Flow cytometric analysis of DNA content for cell cycle distribution. Cells $\left(1 \times 10^{6}\right.$ cells/well) were cultured in 6-well plates in medium containing $10 \% \mathrm{FBS}$, then treated with or without $10 \mu \mathrm{M}$ DPI for different times and analyzed by flow cytometry as previously described (26). Briefly, the cells were harvested, washed and fixed with $70 \%$ ethanol/PBS at $4^{\circ} \mathrm{C}$. Then, the fixed cells were incubated with $0.5 \mathrm{ml} \mathrm{PBS}$ containing $20 \mu \mathrm{g} / \mathrm{ml}$ RNase A for $30 \mathrm{~min}$ at $37^{\circ} \mathrm{C}$ and stained with $50 \mu \mathrm{g} / \mathrm{ml}$ PI for $30 \mathrm{~min}$ before analysis with a FACSCalibur $^{\mathrm{TM}}$ flow cytometer (Becton-Dickinson, San Jose, CA). A minimum of 10,000 cells per sample were counted and the DNA histograms were further analyzed by CellQuest Pro (Becton-Dickinson) and Modfit (Verity Software House, Topsham, ME) software to estimate the percentage of subdiploid DNA at each phase of the cell cycle (27).

Western blot analysis. Equivalent amounts $(20 \mu \mathrm{g})$ of total proteins were loaded onto $12 \%$ SDS-polyacrylamide gels for electrophoresis. The proteins were then transferred onto a nitrocellulose membrane using an electroblotting apparatus (Bio-Rad, Richmond, CA) and the membranes were incubated with each primary antibody. Blots were washed with TBS-T and incubated with an HRP-conjugated secondary anti-rabbit antibody. The membranes were developed with the ECL reaction system and visualized using the LAS-3000 Luminescent Image Analyzer (FujiFilm, Tokyo, Japan). We used ImageGauge Ver. 3.0 software to calculate changes in protein expression. $\beta$-actin was used as an internal control to monitor equal protein sample loading. 
A)

HCT-116

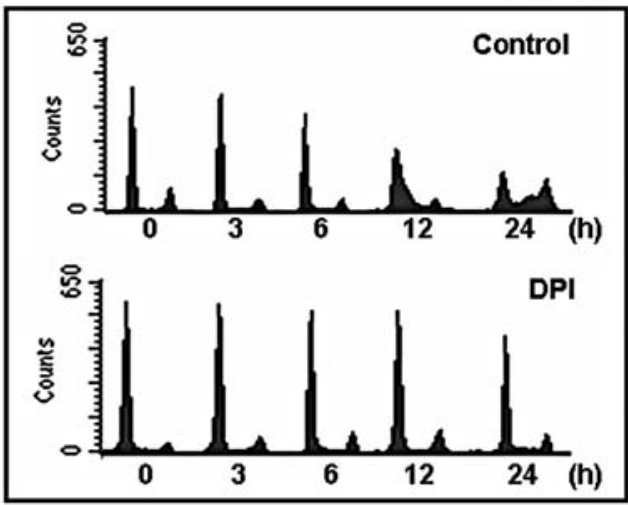

HL-60

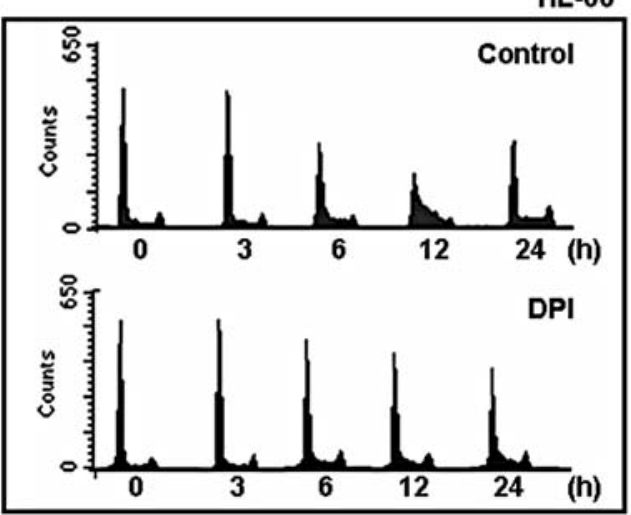

C)
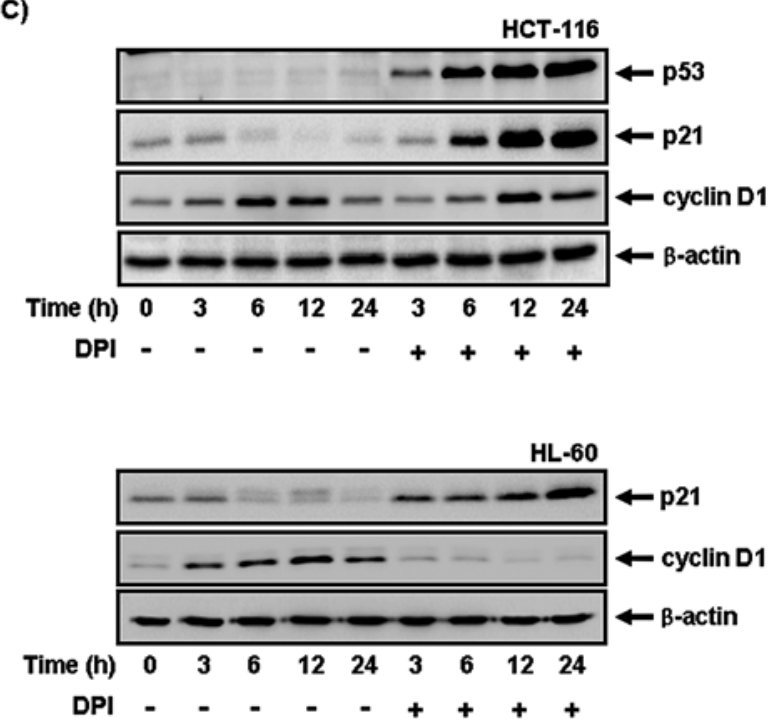

Figure 2. FACS analysis of cell cycle progression and expression pattern of p53, p21 and cyclin D1 by DPI treatment. HCT-116 and HL-60 cells were serum-starved for $48 \mathrm{~h}$ before $10 \%$ FBS with or without $10 \mu \mathrm{M}$ DPI was added to induce the cells to re-enter the cell cycle. (A) Cell cycle distribution analysis by FACS at the indicated time after serum stimulation. (B) Changes in the percentages of cells in $\mathrm{G}_{0} / \mathrm{G}_{1}$ and $\mathrm{S}$ phase using CellQuest software. The results are means \pm SE of three independent experiments. (C) Western blotting for detecting p53, p21 and cyclin D1. B-actin was used as an internal control to monitor equal protein loading.

Transfection of siRNA. To evaluate the role of p53 and p21 in the inhibition of cell cycle progression by DPI, we performed gene silencing assays (18). Briefly, we used 21-nucleotide
B)
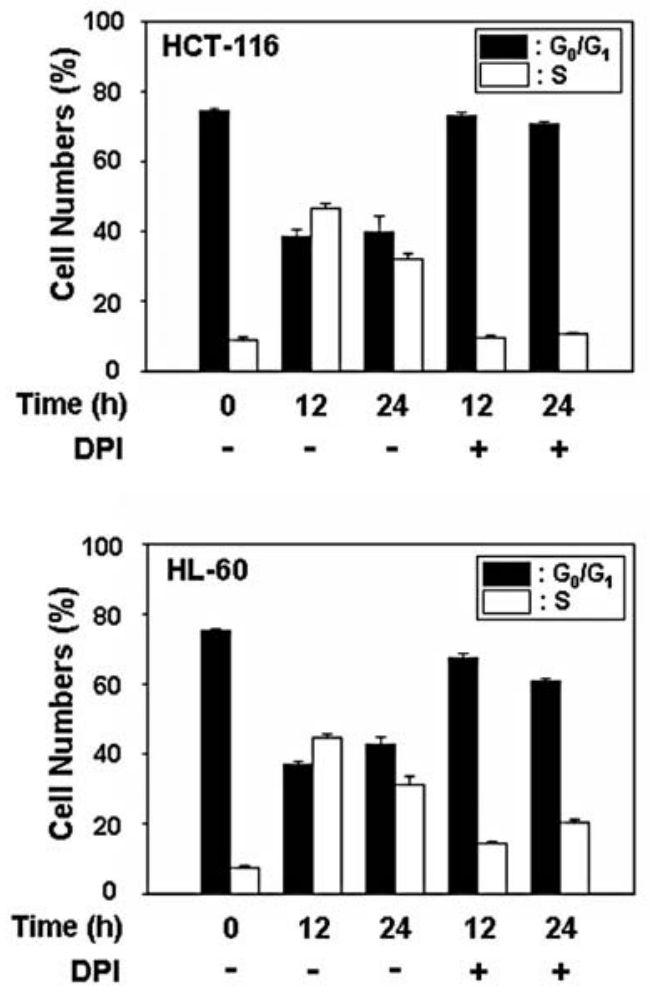

duplex siRNA sequences targeting human p53 and p21 RNA, designed to knockdown human p53 and p21 gene expression (Dharmacon, Lafayette, CO). At $12 \mathrm{~h}$ after plating, cells at $\sim 30 \%$ confluence were transfected with p53 or p21 siRNA using DharmaFECT ${ }^{\circledR}$ Duo transfection reagent plus DMEM or RPMI-1640 medium according to the manufacturer's instructions for $48 \mathrm{~h}$. The cells were then serum-starved for $48 \mathrm{~h}$ and incubated with $10 \mu \mathrm{M}$ DPI or vehicle for another $24 \mathrm{~h}$.

Statistics or reproducibility. Each experiment was repeated at least three times. Data were expressed as the means \pm SE from each independent experiment. The data for the experimental and control groups were tested for statistical significance by a one-tailed Student's t-test, with $\mathrm{P}<0.05$ accepted as the level of significance.

\section{Results}

Effects of DPI on cell viability and proliferation. We first evaluated the effect of DPI, a flavoenzyme inhibitor, on viability and proliferation of HCT-116 (Fig. 1A) and HL-60 (Fig. 1B) cells. Cells were treated with various concentrations of DPI $(2.5,5,10,20$ and $40 \mu \mathrm{M})$ for $24 \mathrm{~h}$, and direct cell counts were determined by trypan blue dye exclusion at the end of each treatment. A dose-dependent reduction in cellular viability was observed after DPI treatments, although the percentage of viable cells remained $>80 \%$ with 2.5 to $10 \mu \mathrm{M}$ DPI for $24 \mathrm{~h}$ treatment in both cell lines. However, a significant decrease in cell numbers was observed with all concentrations of DPI, ranging from 2.5 to $40 \mu \mathrm{M}$, in DPItreated cells. 
A)

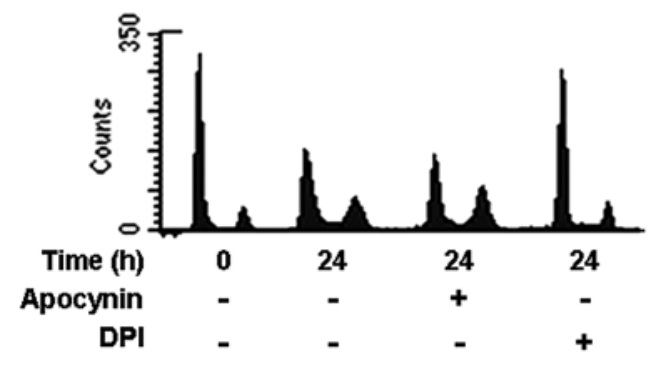

B)

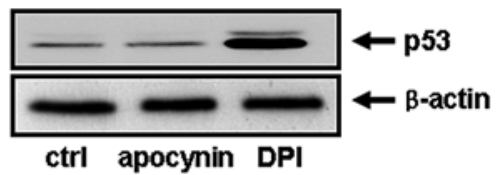

Figure 3. Effects of apocynin on cell cycle progression and expression of p53. HCT-116 cells were serum-starved for $48 \mathrm{~h}$ and exposed to either $1 \mathrm{mM}$ apocynin or $10 \mu \mathrm{M}$ DPI in complete media for $24 \mathrm{~h}$. (A) FACS analysis of cell cycle distribution following apocynin or DPI treatment. (B) Western blot analysis of p53 protein levels. B-actin was used as an internal control to monitor equal protein loading.

Requirement of p53/p21 signaling for DPI-induced $G_{0} / G_{I}$ arrest. As mentioned above, the reduction of cell numbers by DPI seemed to be due to inhibition of cell cycle progression, rather than to an increase of cell death. To further examine the inhibition of cell proliferation by DPI, we investigated the effect of DPI on cell cycle progression in serum-starved cells using flow cytometry with PI staining. Representative flow cytometric experiments are shown in Fig. 2A and B. The percentage of cells synchronized in $\mathrm{G}_{0} / \mathrm{G}_{1}$ was $>70 \%$ upon $48 \mathrm{~h}$ serum starvation. Both cell lines entered $\mathrm{S}$ phase $\sim 8 \mathrm{~h}$ after serum stimulation, with the minimum percentage of cells in $\mathrm{G}_{0} / \mathrm{G}_{1}$ phase observed at $18 \mathrm{~h}$ (data not shown). When both cell lines were treated with DPI, cells were unable to progress into the $\mathrm{S}$ phase.

Although DPI can decrease the cellular generation of ROS, previous studies regarding this activity have been controversial. Indeed, both inhibition (10) and stimulation (28-30) of ROS generation have been reported. Recently, we also showed that DPI significantly induces ROS-independent p53 expression in human RPE cells (18). In parallel, DPI did not induce ROS generation in either HCT-116 or HL-60 cells (data not shown). Therefore, we assessed whether DPI could increase the expression of p53 in HCT-116 cells. Analysis of the expression of p53/p21 in untreated cells revealed that the expression of p53 was unchanged while p21 expression was decreased $6 \mathrm{~h}$ after serum stimulation (Fig. 2C). However, DPI significantly increased p53 expression in HCT-116 cells. In addition, DPI also induced the accumulation of $\mathrm{p} 21$ in both cell types (Fig. 2C).

Interestingly, in contrast to DPI, the specific NADPH oxidase inhibitor apocynin did not have any inhibitory and enhancing effects on cell cycle progression and expression of p53, respectively, in quiescent HCT-116 cells (Fig. 3).

Next, to evaluate the role of $\mathrm{p} 53 / \mathrm{p} 21$ proteins in the inhibition of cell cycle progression, we used siRNA to
A)

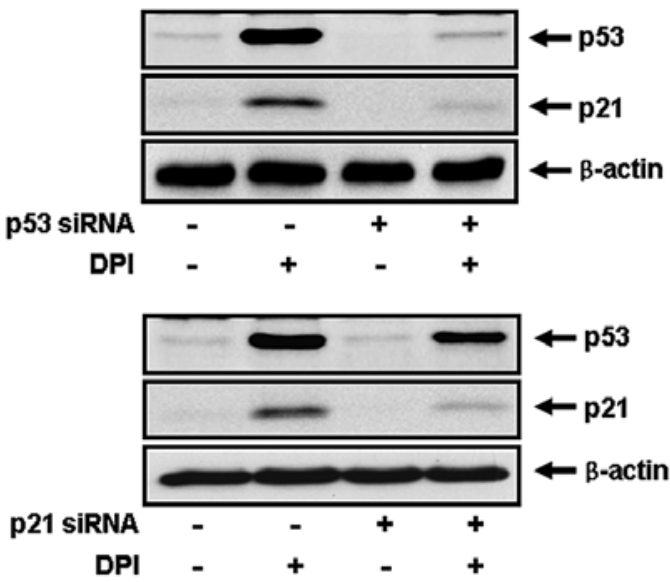

B)

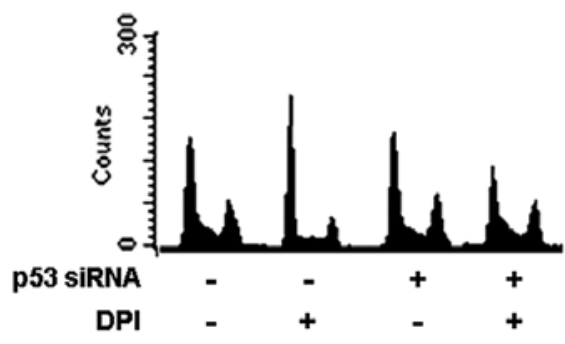

C)

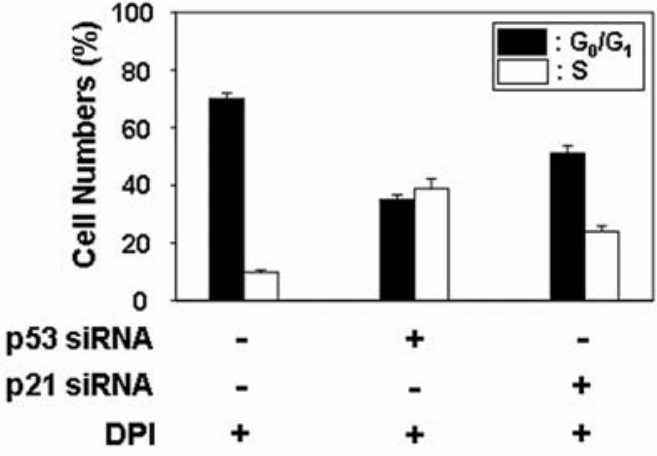

Figure 4. Effects of p53 or p21 siRNA transfection on inhibition of cell cycle progression by DPI treatment. HCT-116 cells were transfected with p53 or p21 siRNA as described in Materials and methods and incubated in the presence or absence of $10 \mu \mathrm{M}$ DPI. After $24 \mathrm{~h}$ stimulation, Western blots were performed to detect p53 and p21 (A) and analysis of cell cycle distribution was performed by FACS (B). (C) Changes in the percentages of cells in $\mathrm{G}_{0} / \mathrm{G}_{1}$ and $\mathrm{S}$ phase were calculated using CellQuest software. The results are means $\pm \mathrm{SE}$ of three independent experiments.

knockdown p53 or p21 in HCT-116. HCT-116 cells were transfected with p53, p21 or a nonspecific control siRNA duplex and then serum-starved for $48 \mathrm{~h}$; the cells were then incubated with $10 \mu \mathrm{M}$ DPI or vehicle for another $24 \mathrm{~h}$. Transfection with the control siRNA duplex did not significantly affect $\mathrm{p} 53 / \mathrm{p} 21$ protein levels relative to untransfected controls (data not shown). DPI-induced p53/ p21 upregulation was completely blocked by transfection 
A)

HCT-116

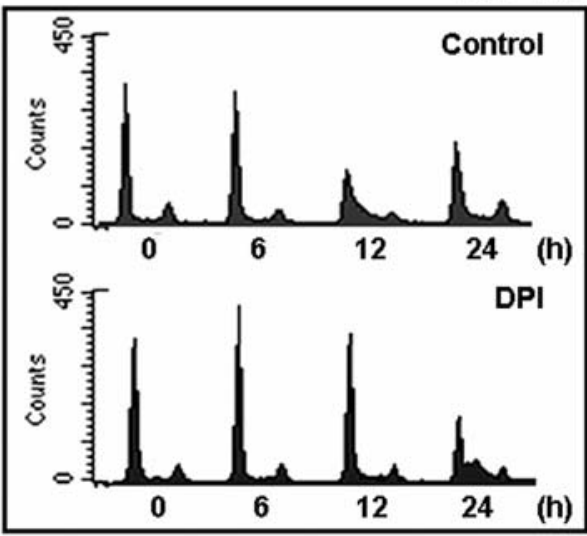

HL-60

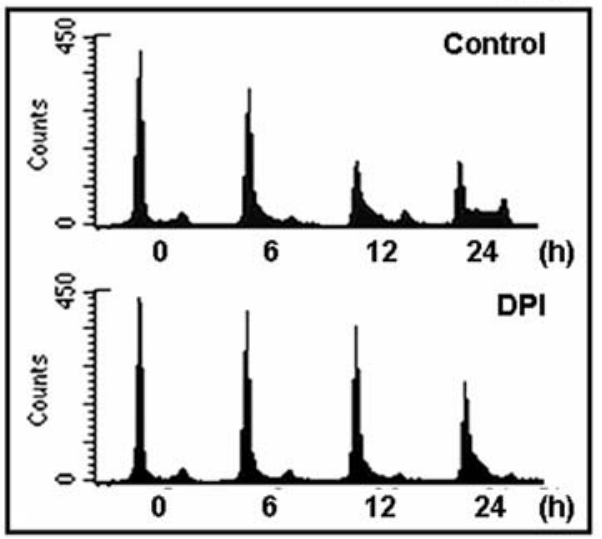

C)
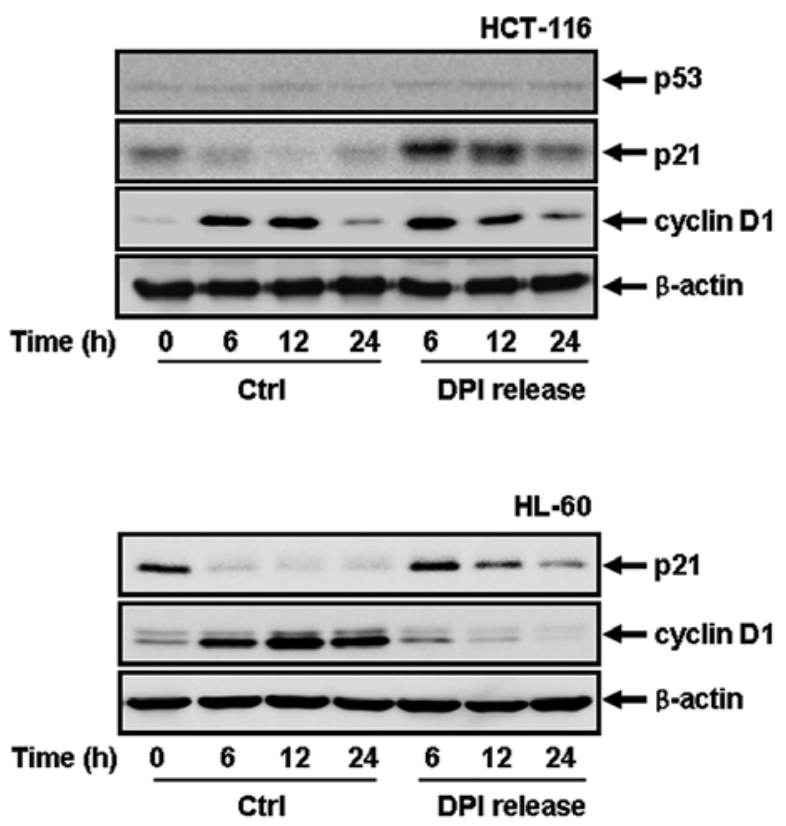

Figure 5. Reversible cell cycle inhibition and time-dependent expression of cell cycle regulatory proteins by DPI release. Quiescent HCT-116 and HL-60 cells were incubated in complete medium with or without $10 \mu \mathrm{M}$ DPI for $1 \mathrm{~h}$. The cells were then released from DPI treatment by washing with regular culture medium without DPI. Cells were continuously incubated in complete media without DPI. (A) Cell cycle distribution analysis at the indicated time point. (B) Changes in the percentages of cells in $\mathrm{G}_{0} / \mathrm{G}_{1}$ and $\mathrm{S}$ phase after DPI release in both cell lines. The results are means $\pm \mathrm{SE}$ of three independent experiments. (C) Western blotting for detecting p53, p21 and cyclin D1. B-actin was used as an internal control to monitor equal protein loading.
B)

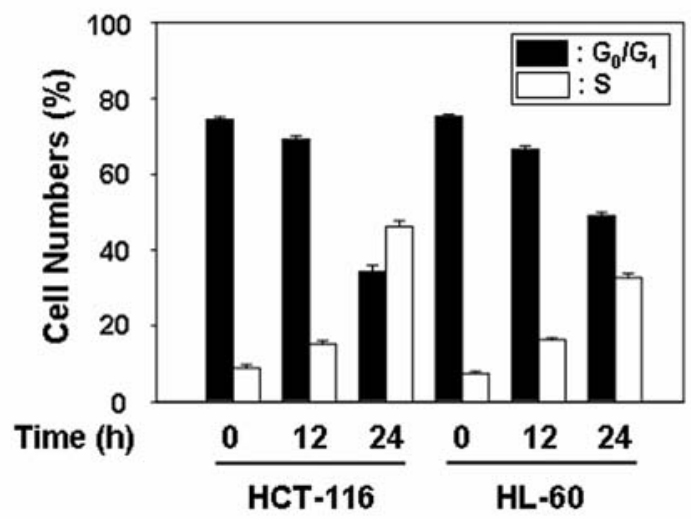

with the respective siRNA and knockdown of p53 expression also significantly impaired p21 upregulation by DPI (Fig. 4).

To confirm the effect of $\mathrm{p} 53 / \mathrm{p} 21$ gene silencing on DPIinduced $\mathrm{G}_{0} / \mathrm{G}_{1}$ arrest, we next analyzed the distribution of cell cycle using flow cytometry. As shown in Fig. 4B and C, p53 or p21 siRNA transfection prevented the inhibition of cell cycle progression by DPI; however, the transition from $\mathrm{G}_{1}$ to $\mathrm{S}$ phase was more efficient with p53 siRNA than with p21 siRNA.

Reversible cell cycle inhibition by release of DPI. To further investigate the role of $\mathrm{p} 53 / \mathrm{p} 21$ signaling in the inhibition of cell cycle progression by DPI, both cell lines were serumstarved for $48 \mathrm{~h}$ and then incubated in complete medium with $10 \mu \mathrm{M}$ DPI. After $1 \mathrm{~h}$ incubation, cells were released from DPI treatment by washing with regular culture medium without DPI. Cells were continuously incubated in complete media without DPI and were harvested at the indicated times for cell cycle and protein expression analyses (Fig. 5). Cells released from DPI showed transient $\mathrm{G}_{0} / \mathrm{G}_{1}$ arrest until $12 \mathrm{~h}$ after release and then progressed into $\mathrm{S}$ phase (Fig. $5 \mathrm{~A}$ and $\mathrm{B}$ ), although much greater fraction cells arrested in $\mathrm{G}_{0} / \mathrm{G}_{1}$ was observed in HL-60 cells than in HCT-116 cells at $24 \mathrm{~h}$ after brief exposure of DPI. Consistent with the results of cell cycle progression after release from DPI, dynamic expression of p21, including transient upregulation and then marked reduction, was detected in DPI-released both cells. Whereas the expression of $\mathrm{p} 53$ was not changed by brief exposure to DPI in HCT-116 cells.

Cyclin D1 in $G_{0} / G_{1}$ arrest by DPI. Cyclin D1 is known to regulate several cyclin-dependent kinases required for cell cycle progression, including for transition from $G_{0}$ to $G_{1}$ or from $\mathrm{G}_{1}$ to $\mathrm{S}$ phase $(31,32)$. In our study, cyclin $\mathrm{D} 1$ expression was significantly elevated $6 \mathrm{~h}$ after serum stimulation in DPIuntreated HCT-116 cells and was also increased with some delay in DPI-treated cells (Fig. 2C). Moreover, the fluctuating expression of cyclin D1 was not affected by brief exposure to DPI in HCT-116 cells. In contrast, treatment of HL-60 cells with DPI significantly impaired cyclin D1 upregulation by serum stimulation (Fig. 2C). Interestingly, as shown in Fig. 5C, the inhibition of cyclin D1 upregulation by DPI was also irreversible in HL-60 cells. 


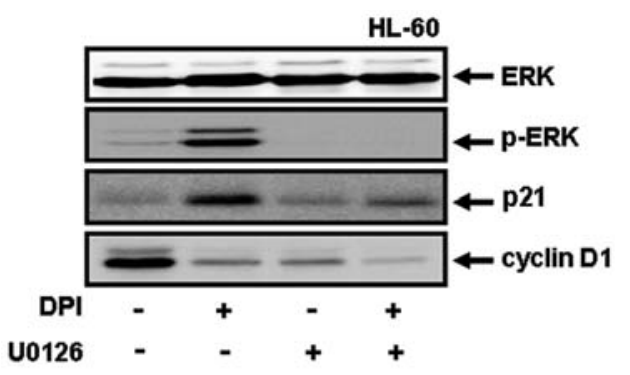

Figure 6. Involvement of ERK activation in DPI-stimulated p21 and cyclin D1 expression. HL-60 cells were pretreated with U0126 for $30 \mathrm{~min}$ and then incubated with $10 \mu \mathrm{M}$ DPI for $24 \mathrm{~h}$. Whole cell extracts were analyzed by Western blot analysis using corresponding antibodies.

Influence of DPI-mediated ERK activation on the expression of p21 and cyclin D1. In order to establish whether MAPK signaling pathway plays a role in the expression of proteins involved in DPI-induced $\mathrm{G}_{0} / \mathrm{G}_{1}$ arrest, activation of classical MAPK (JNK, p38 and ERK1/2) signaling pathways was examined after DPI treatment. In our study, MAPKs were not significantly changed in HCT-116 cells as well as JNK and p38 in HL-60 cells by DPI treatment (data not shown). However, the expression of p-ERK was significantly increased by DPI treatment in HL-60 cells, and DPI-induced p21 upregulation was also impaired by ERK inhibitor, U0126. However, cotreatment of DPI and ERK inhibitor showed synergetic effect on inhibition of cyclin D1 expression compared with DPI alone (Fig. 6)

\section{Discussion}

The nonspecific flavoenzyme inhibitor, DPI, has potent antiproliferative activity in a variety of cell types $(16,33,34)$. Many anticancer strategies that inhibit cell proliferation by blocking cell cycle progression have been used in clinical application for anticancer treatments (35), we tested the possible use of DPI as an anticancer drug in many cancer cell types. In most of the cancer cells tested, such as prostate, colon, leukemia and breast cancer cells, cell proliferation was potently inhibited (data not shown). Among these cancer cells, two cell lines, HL-60 (null p53) and HCT-116 (wild-type p53) cancer cells, exhibited differential patterns of regulation of cell cycle regulatory factors induced by DPI.

Generally, the cyclin-dependent kinase inhibitor, p21, is known to mediate cell cycle arrest in a p53-dependent or -independent manner (36-38). In this study, remarkable induction of p21 was observed at early time points of DPI treatment in both cancer cell lines and p53 expression was increased by DPI in HCT-116 cells. To investigate the role of p53 in $G_{0} / G_{1}$ arrest and p21 upregulation by DPI treatment, knockdown of p53 expression by siRNA transfection significantly impaired DPI-induced p21 upregulation, permitting transition from $\mathrm{G}_{0} / \mathrm{G}_{1}$ to $\mathrm{S}$ phase in HCT-116 cells. Transfection of p21 siRNA with DPI treatment increased the progression into $\mathrm{S}$ phase compared with treatment of DPI alone; however transfection of p53 siRNA allowed more efficient transition into $\mathrm{S}$ phase. These results suggest that the upregulation of p53 is the main regulator of inhibition of cell cycle progression by DPI in HCT-116 cells and that
$\mathrm{G}_{0} / \mathrm{G}_{1}$ arrest by DPI requires an additional downstream factor regulated by $\mathrm{p} 53$ in addition to the upregulation of $\mathrm{p} 21$. Interestingly, brief exposure to DPI resulted in no change in the expression of p53, but transient upregulation of p21 and $\mathrm{G}_{0} / \mathrm{G}_{1}$ arrest; that is, the upregulation of $\mathrm{p} 53$ by DPI was associated with maintaining $\mathrm{G}_{0} / \mathrm{G}_{1}$ arrest and $\mathrm{p} 21$ upregulation rather than with their initiation in HCT-116 cells. However, further studies are needed to determine whether p53 was related to stabilization of $\mathrm{p} 21$ expression or to secondary regulation of the p21 transcript level after its initial induction. Ordinarily, p53 is known to activate p21 at the transcriptional level (36).

DPI has frequently been used to inhibit ROS production mediated by various flavoenzymes $(2,39,40)$. In our study, DPI treatment showed significant inhibition of ROS generation in normal cells and complete inhibition of ROS production by serum stimulation in quiescent cells (data not shown). The spontaneous cleavage product of DPI, a benzene radical, combines with the flavin semiquinone, resulting in covalent modification of redox proteins containing the flavin moiety and irreversible inactivation of many redox-active proteins, including flavoenzymes $(6,8)$. Cyclin D1 function is known to be important in redox regulation of cell cycle re-entry (41), and DPI remarkably inhibited the induction of cyclin D1 needed for cell cycle re-entry through inhibition of Nox activity (16). We showed that DPI significantly impaired cyclin D1 upregulation by serum stimulation and downregulation of cyclin D1 by DPI was also irreversible in HL-60 cells. However, in HCT-116 cells, cyclin D1 expression was not significantly affected by DPI treatment. In addition, a greater fraction of $\mathrm{G}_{0} / \mathrm{G}_{1}$ phase was observed in HL-60 cells than HCT-116 cells after release from DPI. These results suggest that cyclin D1 is an important regulatory factor for the inhibition of cell cycle progression by DPI in HL-60 cells and that the irreversible fraction of HL-60 cells arrested in $\mathrm{G}_{0} / \mathrm{G}_{1}$ by brief exposure to DPI might be caused by an irreversible decrease of cyclin D1. Irreversible inactivation of certain flavoenzymes might be the reason for the cyclin D1 downregulation.

MAPK signaling pathways control the cell growth and survival of broad range. ERK signaling pathways have been reported to regulate $\mathrm{p} 21$ expression at transcriptional or post-transcriptional level (42). Moreover, ERK signaling pathways along with $\mathrm{p} 38$ have been known to cooperate to induce p21 expression for $\mathrm{G}_{1}$ cell cycle arrest (43). In this study, we demonstrate that DPI induced upregulation of p21 and downregulation of cyclin D1 are regulated by two distinct mechanisms such as ERK-mediated and ERKindependent regulation, respectively, in HL-60 cells. Generally, activation of ERK1/2 is required for cyclin D1 transcription in most cell types (44). Concomitant with these results, inhibition of ERK activation relieved the expression of cyclin D1 in HL-60 cells. Thus, the decrease in cyclin D1 despite of ERK activation in DPI-treated cells suggest that unlike p21, regulation of cyclin D1 expression is independent of ERK signaling pathway. However, unlike HL-60 cells, the MAPK signaling pathways are not significantly changed in HCT- 116 cells undergo $\mathrm{G}_{0} / \mathrm{G}_{1}$ arrest by DPI treatment.

In conclusion, our results demonstrate that DPI can block the transition from $G_{0} / G_{1}$ to $S$ phase accompanied by induction 
of p21 and that upregulation of p53 sustain $\mathrm{G}_{0} / \mathrm{G}_{1}$ cell cycle arrest and upregulation of p 21 by DPI in HCT-116 cells. In HL-60 cells, inhibition of cell cycle progression by DPI is achieved through the cooperation of cyclin D1 downregulation and p53-independent upregulation of p21.

\section{Acknowledgements}

This study was supported by the MRC program of MOST/ KOSEF (R13-2005-009).

\section{References}

1. Cross AR and Jones OT: The effect of the inhibitor diphenylene iodonium on the superoxide-generating system of neutrophils. Specific labelling of a component polypeptide of the oxidase. Biochem J 237: 111-116, 1986.

2. O'Donnell BV, Tew DG, Jones OT and England PJ: Studies on the inhibitory mechanism of iodonium compounds with special reference to neutrophil NADPH oxidase. Biochem J 290: 41-49, 1993.

3. Stuehr DJ, Fasehun OA, Kwon NS, Gross SS, Gonzalez JA, Levi R and Nathan CF: Inhibition of macrophage and endothelial cell nitric oxide synthase by diphenyleneiodonium and its analogs. FASEB J 5: 98-103, 1991 .

4. Tew DG: Inhibition of cytochrome P450 reductase by the diphenyliodonium cation. Kinetic analysis and covalent modifications. Biochemistry 32: 10209-10215, 1993.

5. Coves J, Lebrun C, Gervasi G, Dalbon P and Fontecave M: Overexpression of the FAD-binding domain of the sulphite reductase flavoprotein component from Esherichia coli and its inhibition by iodonium diphenylchloride. Biochem J 342: 465-472, 1999 .

6. Chakraborty S and Massey V: Reaction of reduced flavins and flavoproteins with diphenyliodonium chloride. J Biol Chem 277: 41507-41516, 2002.

7. Sanders SA, Eisenthal R and Harrison R: NADH oxidase activity of human xanthine oxidoreductase-generation of superoxide anion. Eur J Biochem 245: 541-548, 1997.

8. O'Donnell VB, Smith GC and Jones OT: Involvement of phenyl radicals in iodonium inhibition of flavoenzymes. Mol Pharmacol 46: 778-785, 1994

9. Doussiere J, Gaillard J and Vignais PV: The heme component of the neutrophil NADPH oxidase complex is a target for aryliodonium compounds. Biochemistry 38: 3694-3703, 1999.

10. Li Y and Trush MA: Diphenyleneiodonium, an NAD(P)H oxidase inhibitor, also potently inhibits mitochondrial reactive oxygen species production. Biochem Biophys Res Commun 18: 295-299, 1998.

11. Pandian RP, Kutala VK, Liaugminas A, Parinandi NL and Kuppusamy P: Lipopolysaccharide-induced alterations in oxygen consumption and radical generation in endothelial cells. Mol Cell Biochem 278: 119-127, 2005.

12. Joneson T and Bar-Sagi DA: Rac1 effector site controlling mitogenesis through superoxide production. J Biol Chem 273: 17992-17994, 1998.

13. Finkel $\mathrm{T}$ and Holbrook NJ: Oxidants, oxidative stress and the biology of ageing. Nature 408: 239-247, 2000.

14. Burch PM, Yuan Z, Loonen A and Heintz NH: An extracellular signal-regulated kinase 1 - and 2-dependent program of chromatin trafficking of c-Fos and Fra-1 is required for cyclin D1 expression during cell cycle reentry. Mol Cell Biol 24: 4696-4709, 2004

15. Yuan Z, Schellekens H, Warner L, Janssen-Heininger Y, Burch $P$ and Heintz NH: Reactive nitrogen species block cell cycle re-entry through sustained production of hydrogen peroxide. Am J Respir Cell Mol Biol 28: 705-712, 2003.

16. Ranjan P, Anathy V, Burch PM, Weirather K, Lambeth JD and Heintz NH: Redox-dependent expression of cyclin D1 and cell proliferation by Nox1 in mouse lung epithelial cells. Antioxid Redox Signal 8: 1447-1459, 2006.

17. Scaife RM: G2 cell cycle arrest, down-regulation of cyclin B, and induction of mitotic catastrophe by the flavoprotein inhibitor diphenyleneiodonium. Mol Cancer Ther 3: 1229-1237, 2004.
18. Park SE, Song JD, Kim KM, Park YM, Kim ND, Yoo YH and Park YC: Diphenyleneiodonium induces ROS-independent p53 expression and apoptosis in human RPE cells. FEBS Lett 581: 180-186, 2007.

19. White AE, Livanos EM and Tlsty TD: Differential disruption of genomic integrity and cell cycle regulation in normal human fibroblasts by the HPV oncoproteins. Genes Dev 8: 666-677, 1994.

20. Amundson SA, Myers TG and Fornace AJ Jr: Roles for p53 in growth arrest and apoptosis: putting on the brakes after genotoxic stress. Oncogene 17: 3287-3299, 1998.

21. Vousden KH: p53: death star. Cell 103: 691-694, 2000

22. Sherr CJ and Roberts JM: CDK inhibitors: positive and negative regulators of $\mathrm{G}_{1}$-phase progression. Genes Dev 13: 1501-1512, 1999.

23. Fang L, Igarashi M, Leung J, Sugrue MM, Lee SW and Aaronson SA: p21Waf1/Cip1/Sdi1 induces permanent growth arrest with markers of replicative senescence in human tumor cells lacking functional p53. Oncogene 18: 2789-2797, 1999.

24. Venkatachalam P, de Toledo SM and Azzam EI: Flavincontaining oxidases regulate progression from $\mathrm{G}_{1}$ to $\mathrm{S}$ phase of the cell cycle in normal human diploid fibroblasts. Radiat Phys Chem 72: 315-321, 2005.

25. Lam EW and Watson RJ: An E2F-binding site mediates cell-cycle regulated repression of mouse B-myb transcription. EMBO J 12: 2705-2713, 1993

26. Jo HJ, Song JD, Kim KM, Cho YH, Kim KH and Park YC: Diallyl disulfide induces reversible $\mathrm{G} 2 / \mathrm{M}$ phase arrest on a p53-independent mechanism in human colon cancer HCT-116 cells. Oncol Rep 19: 275-280, 2008.

27. Wang XW, Zhan Q, Coursen JD, Khan MA, Kontny HU, Yu L, Hollander MC, O'Connor PM, Fornace AJ and Harris CC: GADD45 induction of a $\mathrm{G}_{2} / \mathrm{M}$ cell cycle checkpoint. Proc Natl Acad Sci USA 96: 3706-3711, 1999.

28. Balcerczyk A, Soszynski M, Rybaczek D, Przygodzki T, Karowicz-Bilinska A, Maszewski J and Bartosz G: Induction of apoptosis and modulation of production of reactive oxygen species in human endothelial cells by diphenyleneiodonium. Biochem Pharmacol 69: 1263-1273, 2005.

29. Riganti C, Gazzano E, Polimeni M, Costamagna C, Bosia A and Ghigo D: Diphenyleneiodonium inhibits the cell redox metabolism and induces oxidative stress. J Biol Chem 279: 47726-47731, 2004.

30. Li N, Ragheb K, Lawler G, Sturgis J, Rajwa B, Melendez JA and Robinson JP: DPI induces mitochondrial superoxide-mediated apoptosis. Free Radic Biol Med 34: 465-477, 2003.

31. Draetta GF: Mammalian G1 cyclins. Curr Opin Cell Biol 6: 842-846, 1994.

32. Sherr CJ: D-type cyclins. Trends Biochem Sci 20: 187-190, 1995.

33. Brar SS, Corbin Z, Kennedy TP, Hemendinger R, Thomton L, Bommarius B, Arnold RS, Whorton AR, Sturrock AB, Huecksteadt TP, Quinn MT, Krenitsky K, Ardie KG, Lambeth JD and Hoidal JR: NOX5 NAD(P)H oxidase regulates growth and apoptosis in DU 145 prostate cancer cell. Am J Physiol Cell Physiol 285: C353-C369, 2003.

34. Scaife RM: Selective and irreversible cell cycle inhibition by diphenyleneiodonium. Mol Cancer Ther 4: 876-884, 2005.

35. Stewart ZA, Westfall MD and Pietenpol JA: Cell-cycle dysregulation and anticancer therapy. Trends Pharmacol Sci 24: 139-145, 2003.

36. el-Deiry WS, Tokino T, Velculescu VE, Levy DB, Parsons R, Trent JM, Lin D, Mercer WE, Kinzler KW and Vogelstein B: WAF1, a potential mediator of p53 tumor suppression. Cell 75: $817-825,1993$.

37. Sankala HM, Hait NC, Paugh SW, Shida D, Lépine S, Elmore LW, Dent P, Milstien S and Spiegel S: Involvement of sphingosine kinase 2 in p53-independent induction of p21 by the chemotherapeutic drug doxorubicin. Cancer Res 67: 10466-10474, 2007.

38. Huo JX, Metz SA and Li GD: p53-independent induction of $\mathrm{p} 21$ (waf1/cip1) contributes to the activation of caspases in GTP-depletion-induced apoptosis of insulin-secreting cells. Cell Death Differ 11: 99-109, 2004

39. Chen L, Yu LJ and Waxman DJ: Potentiation of cytochrome P450/cyclophosphamide-based cancer gene therapy by coexpression of the P450 reductase gene. Cancer Res 57: 4830-4837, 1997.

40. Wever RM, van Dam T, van Rijn HJ, de Groot F and Rabelink TJ: Tetrahydrobiopterin regulates superoxide and nitric oxide generation by recombinant endothelial nitric oxide synthase. Biochem Biophys Res Commun 237: 340-344, 1997. 
41. Burch PM and Heintz NH: Redox regulation of cell-cycle reentry: cyclin D1 as a primary target for the mitogenic effects of reactive oxygen and nitrogen species. Antioxid Redox Signal 7: 741-751, 2005.

42. Ciccarelli C, Marampon F, Scoglio A, Mauro A, Giacinti C, De Cesaris P and Zani BM: p21WAF1 expression induced by MEK/ERK pathway activation or inhibition correlates with growth arrest, myogenic differentiation and onco-phenotype reversal in rhabdomyosarcoma cells. Mol Cancer 4: 41, 2005.
43. Todd DE, Densham RM, Molton SA, Balmanno K, Newson C, Weston CR, Garner AP, Scott L and Cook SJ: ERK1/2 and p38 cooperate to induce a p21CIPI-dependent G1 cell cycle arrest. Oncogene 23: 3284-3295, 2004.

44. Huang S and Ingber DE: A discrete cell cycle checkpoint in late $\mathrm{G}(1)$ that is cytoskeleton-dependent and MAP kinase (Erk)independent. Exp Cell Res 275: 255-264, 2002. 